\title{
Efficacy and safety of low-dose aspirin combined with low-molecular-weight heparin in treatment of preeclampsia: a meta-analysis and systematic review
}

Chunfeng Wu, Liling Li, Jiarong Zhang, Yang Song

Department of Obstetrics, Shenzhen Longhua Maternity and Child Healthcare Hospital, Shenzhen, China

Submitted: 14 March 2021, Accepted: 11 May 2021

Online publication: 24 May 2021

Arch Med Sci 2022; 18 (6): 1525-1534

DOI: https://doi.org/10.5114/aoms/136518

Copyright $\odot 2021$ Termedia \& Banach

\section{Abstract}

Introduction: The role of low-dose aspirin combined with low-molecular-weight heparin (LMWH) in the treatment of preeclampsia (PE) remains unclear. We aimed to assess the efficacy and safety of low-dose aspirin combined with $\mathrm{LMWH}$ in PE treatment, to provide evidence for clinical PE management.

Material and methods: We searched PubMed and other databases for randomized controlled trials (RCTs) on the effects and safety of low-dose aspirin and LMWH in the treatment of PE up to January 31, 2021. Two researchers strictly followed the inclusion and exclusion criteria to independently conduct the literature screening, data extraction and quality evaluation. We used RevMan 5.3 statistical software for synthesized analysis.

Results: A total of 8 RCTs involving 861 patients were included. The synthesized outcome indicated that the differences in systolic blood pressure $(M D=-10.61,95 \% \mathrm{Cl}:-13.19--8.02)$, diastolic blood pressure $(M D=-9.24,95 \% \mathrm{Cl}:-14.49--4.00), 24$-hour urinary protein $(M D=-2.24$, $95 \% \mathrm{Cl}:-3.97--0.50)$, prothrombin time $(M D=1.42,95 \% \mathrm{Cl}: 0.53-2.32)$, activated partial thromboplastin time $(M D=2.91,95 \% \mathrm{Cl}: 2.06-3.75)$, FIB $(M D=-1.24,95 \% \mathrm{Cl}:-1.32--1.15)$, and adverse perinatal outcomes $(\mathrm{MD}=0.41,95 \% \mathrm{Cl}: 0.20-0.85)$ between the two groups were statistically significant (all $p<0.05$ ), while the difference in the adverse reactions of pregnant women $(\mathrm{MD}=0.44,95 \% \mathrm{Cl}: 0.18-1.10)$ between the two groups was not statistically significant $(p=0.08)$. No publication bias was detected in all the synthesized outcomes (all $p>0.05$ ).

Conclusions: Low-dose aspirin combined with LMWH treatment of PE may be advantageous to improve blood pressure, 24-hour proteinuria and coagulation function, and it may reduce the adverse reactions in pregnant women without increasing adverse perinatal outcomes.

Key words: dose, aspirin, low-molecular-weight heparin, preeclampsia, treatment, meta-analysis.

\section{Introduction}

Preeclampsia (PE), as a kind of hypertension during pregnancy, is one of the important factors associated with maternal and perinatal death [1]. Studies [2, 3] have shown that among the factors leading to maternal death, PE ranks the third, second only to bleeding and thrombosis. It has been reported $[4,5]$ that more than 60,000 pregnant women die

\author{
Corresponding author: \\ Chunfeng Wu \\ Department of Obstetrics \\ Shenzhen Longhua \\ Maternity and Child \\ Healthcare Hospital \\ 68 Huawang Road \\ Dalang Street \\ Longhua District \\ Shenzhen, China \\ Phone: 18646321726 \\ Fax: 001211734016 \\ E-mail: \\ iflpea8406284062@163.com
}


of PE worldwide every year. PE has serious effects on both the mother and the fetus. If effective treatment is not carried out in time, complications such as pulmonary edema and placental abruption may occur in the mother; complications such as intrauterine growth restriction, premature delivery, respiratory distress syndrome and even death may occur in the fetus $[6,7]$. At the same time, PE can also cause serious adverse effects on re-pregnancy; that is, women with a history of $\mathrm{PE}$ have $25 \%$ to $65 \%$ risk of recurrence of $\mathrm{PE}, 3 \%$ risk of placental abruption, and $10 \%$ risk of fetal growth restriction [8-10]. Therefore, early diagnosis and effective treatment of PE are essential for the prognosis of patients.

At present, anticoagulant therapy is commonly used clinically. Aspirin and low molecular weight heparin (LMWH) are the most commonly used drugs [11]. The effectiveness and safety of aspirin in the prevention and treatment of PE have been confirmed by a number of studies [12, 13], but there are still controversies regarding the effect and safety of LMWH in the prevention and treatment of PE. There are very few research reports about the applications of aspirin and LMWH in the treatment of PE. Therefore, the effects and safety of aspirin combined with LMWH in the treatment of PE are still controversial. Therefore, this metaanalysis aimed to systematically evaluate the effectiveness and safety of aspirin combined with $\mathrm{LMWH}$ in the treatment of $\mathrm{PE}$, and to provide an evidence-based reference for the rational use of $\mathrm{PE}$ therapy in clinical practice.

\section{Material and methods}

We conducted and presented this meta-analysis in compliance with the Preferred Reporting Items for Systematic Reviews and Meta-Analyses (PRISMA) [14].

\section{Search strategy}

We searched the potential related randomized controlled trials (RCTs) with reference to the search strategy formulated by the Cochrane Collaboration. We searched PubMed, EMBASE, Science Direct, Cochrane Central Register of Controlled Trials, China National Knowledge Infrastructure (CNKI), Weipu Database, Wanfang Database, and Chinese Biomedical Literature Database for RCTs on the effects of low-dose aspirin and $\mathrm{LMWH}$ in the treatment of PE. The search deadline was January 31, 2021. The search terms included: aspirin, low molecular weight heparin, $\mathrm{LMWH}$, preeclampsia, and the search terms were combined according to the rules of different databases.

The search strategies were jointly formulated by two researchers. According to the established search strategy, the two researchers independently completed the inclusion of the literature, discussed and decided when there were differences, and finally integrated the collected information and data. The research screening process was as follows: preliminary screening of the retrieved documents through the research title and $a b$ stract, then further screening through the full text, and finally in strict accordance with the literature inclusion criteria and exclusion criteria to determine the final inclusion of the literature.

\section{Inclusion and exclusion criteria}

The inclusion criteria for this meta-analysis were: (1) the patient was diagnosed with $\mathrm{PE}$; (2) RCT study design; (3) the treatment method included the combined use of low-dose aspirin and LMWH; (4) aspirin dose $<150 \mathrm{mg} /$ day; (5) the outcome data could be extracted. The exclusion criteria for this meta-analysis were: (1) animal experimental research, conference abstracts and review articles, retrospective research; (2) studies that lack a control group; (3) articles that were repeatedly published.

\section{Data extraction}

Two authors independently evaluated and extracted the data, including: systolic blood pressure, diastolic blood pressure, 24-hour urinary protein, prothrombin time (PT), activated partial thromboplastin time (APTT), fibrinogen (FIB), adverse perinatal outcomes and adverse reactions of pregnant women.

\section{Quality and bias evaluation}

We used Cochrane's risk of bias assessment tool [15] to evaluate the quality and bias of the included RCTs. Seven items were designed to evaluate the risk of bias from the following 6 aspects: (1) sample selection (including random sequence generation and allocation hiding); (2) program implementation (including blinding researchers and subjects); (3) outcome measurement (blind evaluation of study outcome); (4) follow-up (completeness of outcome data); (5) report (selective report of study results); (6) other sources of bias. Each item was rated as "low risk", "high risk" or "unclear" according to the criteria.

\section{Statistical analysis}

We used RevMan5.3 statistical software for meta-analysis. The odds ratio (OR) and its 95\% confidence interval $(95 \% \mathrm{Cl})$ were used as the statistics of the combined effect of the count data; the mean difference (MD) and its $95 \% \mathrm{Cl}$ were used as the statistics of the combined effect of 
the continuous data. The heterogeneity was evaluated by the chi-square test. If the heterogeneity difference between the studies was not statistically significant $\left(p>0.10\right.$ or $\left.p^{2}<50 \%\right)$, the combined effect was analyzed by the fixed effects model; otherwise, the random effects model was used for the meta-analysis. In this study, $p<0.05$ was considered statistically significant.

\section{Results}

\section{Literature search results}

We obtained 118 articles from the initial search. Then we screened out 71 articles by screening titles, abstracts, and duplicate articles. We performed full-text reading of these articles for further screening, and finally included 8 RCTs [16-23]. The study selection process is shown in Figure 1.

\section{Characteristics of included RCTs}

Amongst the 8 RCTs included, a total of 861 patients were involved. The basic characteristics of each study are shown in Table I. Generally, the control group received conventional treatment, and the experimental group was treated with lowdose aspirin combined with LMWH on the basis of the treatment of the control group.

\section{Bias risk assessment}

The evaluation results of the Cochrane bias risk assessment tool for 8 included RCTs were as follows: (1) only 5 RCTs [16-18, 22, 23] described specific random sequence generation methods, but the other 3 RCTs [19-21] did not describe specific randomization methods; (2) none of the studies reported specific allocation concealment; (3) none of the studies reported the specific blinding settings; (4) none of the studies described blind evaluation of the outcome; (5) no missing data were found; (6) all pre-set indicators were reported, and no research with reporting bias was found; (7) no other biases were found. The quality and bias evaluation results of the included RCTs are shown in Figures 2 and 3.

\section{Meta-analysis \\ Systolic blood pressure}

Four RCTs [16, 19, 21, 23] reported the systolic blood pressure. There was no statistical heterogeneity among the studies $\left({ }^{2}=44 \%, p=0.15\right)$. Therefore, a fixed effect model was used. The synthesized outcome indicated that the difference in systolic blood pressure between the two groups was statistically significant (MD $=-10.61,95 \% \mathrm{Cl}$ : $-13.19--8.02, p<0.001$ ) (Figure $4 \mathrm{~A}$ ).

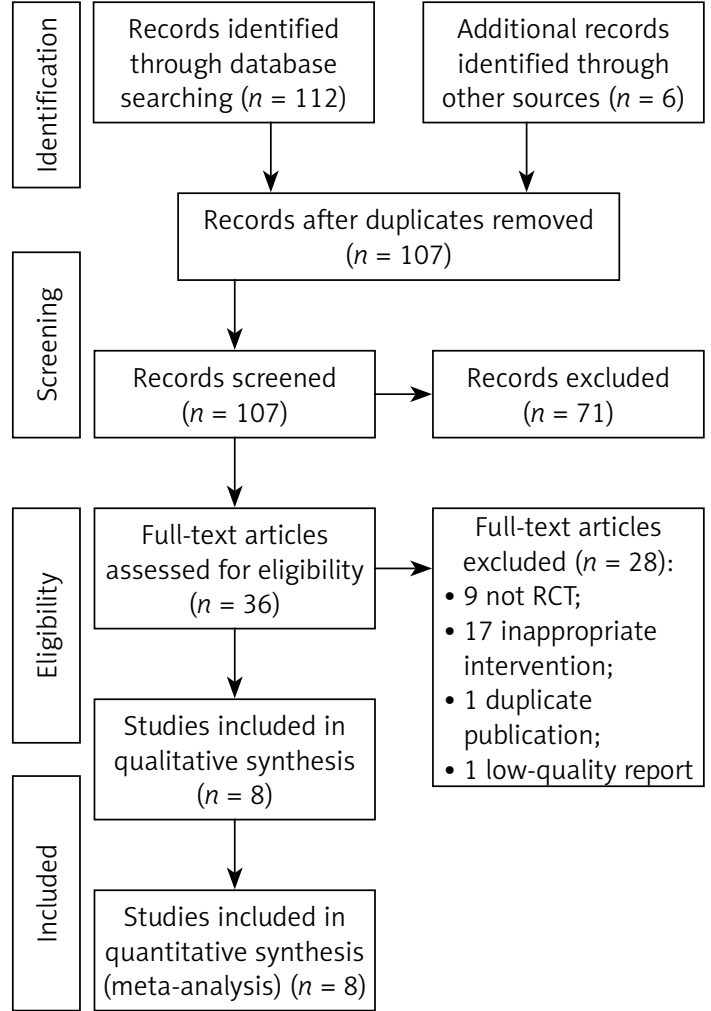

Figure 1. PRISMA flow diagram of study inclusion

\section{Diastolic blood pressure}

Five RCTs [16-19, 23] reported the diastolic blood pressure. There was statistical heterogeneity among the studies $\left(R^{2}=93 \%, p<0.001\right)$. Therefore, a random effect model was used. The synthesized outcome indicated that the difference in diastolic blood pressure between the two groups was statistically significant $(\mathrm{MD}=-9.24,95 \% \mathrm{Cl}$ : $-14.49-4.00, p<0.001$ ) (Figure $4 \mathrm{~B}$ ).

\section{4-hour urinary protein}

Five RCTs $[16-19,22]$ reported the 24-hour urinary protein. There was statistical heterogeneity among the studies $\left(r^{2}=99 \%, p<0.001\right)$. Therefore, a random effect model was used. The synthesized outcome indicated that the difference in 24-hour urinary protein between the two groups was statistically significant (MD $=-2.24,95 \% \mathrm{Cl}$ : $-3.97-$ $-0.50, p=0.01$ ) (Figure $4 \mathrm{C}$ ).

\section{PT}

Five RCTs [16, 18-20, 23] reported the PT. There was statistical heterogeneity among the studies $\left(I^{2}=94 \%, p<0.001\right)$. Therefore, a random effect model was used. The synthesized outcome indicated that the difference in PT between the two groups was statistically significant $(M D=1.42$, 95\% Cl: 0.53-2.32, $p=0.002$ ) (Figure $4 \mathrm{D}$ ). 
Table I. Characteristics of included RCTs

\begin{tabular}{|c|c|c|c|c|c|c|c|c|c|}
\hline \multirow[t]{2}{*}{ Study } & \multicolumn{4}{|c|}{ Experimental group } & \multicolumn{4}{|c|}{ Control group } & \multirow{2}{*}{$\begin{array}{c}\text { Follow-up } \\
\text { period }\end{array}$} \\
\hline & $\begin{array}{l}\text { Sample } \\
\text { size }\end{array}$ & $\begin{array}{c}\text { Age } \\
\text { [years] }\end{array}$ & $\begin{array}{l}\text { Gesta- } \\
\text { tional } \\
\text { weeks }\end{array}$ & Treatment & $\begin{array}{l}\text { Sample } \\
\text { size }\end{array}$ & $\begin{array}{c}\text { Age } \\
\text { [years] }\end{array}$ & $\begin{array}{l}\text { Gesta- } \\
\text { tional } \\
\text { weeks }\end{array}$ & Treatment & \\
\hline $\begin{array}{l}\text { Qiao } \\
2017\end{array}$ & 150 & $\begin{array}{l}26.20 \\
\pm 7.38\end{array}$ & $\begin{array}{l}31.04 \\
\pm 1.30\end{array}$ & $\begin{array}{c}25 \mathrm{mg}^{\star} 2 \text { times/d } \\
\text { aspirin }+5000 \mathrm{U}^{*} \\
\text { times } / \mathrm{d} \text { LMWH }\end{array}$ & 150 & $\begin{array}{l}25.22 \\
\pm 6.40\end{array}$ & $\begin{array}{l}31.04 \\
\pm 1.22\end{array}$ & $\begin{array}{c}\text { Maternal and } \\
\text { fetal monitoring, } \\
\text { blood pressure } \\
\text { control }\end{array}$ & $\begin{array}{l}7 \text { days, } \\
\text { after } \\
\text { childbirth }\end{array}$ \\
\hline $\begin{array}{l}\text { Li } \\
2017\end{array}$ & 65 & $\begin{array}{l}28.40 \\
\pm 4.90\end{array}$ & $\begin{array}{l}31.60 \\
\pm 2.20\end{array}$ & $\begin{array}{c}60 \mathrm{mg}^{\star} \text { times } / \mathrm{d} \\
\text { aspirin } \\
+4000 \mathrm{U}^{\star} \text { times } / \mathrm{d} \\
\mathrm{LMWH}\end{array}$ & 62 & $\begin{array}{l}27.20 \\
\pm 3.70\end{array}$ & $\begin{array}{l}30.30 \\
\pm 2.00\end{array}$ & $\begin{array}{c}\text { Maternal and } \\
\text { fetal monitoring, } \\
\text { blood pressure } \\
\text { control }\end{array}$ & $\begin{array}{l}7 \text { days, } \\
\text { after } \\
\text { childbirth }\end{array}$ \\
\hline $\begin{array}{l}\text { Deng } \\
2018\end{array}$ & 42 & $\begin{array}{l}27.68 \\
\pm 4.31\end{array}$ & NA & $\begin{array}{c}60 \mathrm{mg}^{\star} \text { times } / \mathrm{d} \\
\text { aspirin } \\
+4000 \mathrm{U}^{\star} \text { times } / \mathrm{d} \\
\mathrm{LMWH}\end{array}$ & 42 & $\begin{array}{l}27.08 \\
\pm 3.46\end{array}$ & NA & $\begin{array}{c}\text { Maternal and } \\
\text { fetal monitoring, } \\
\text { blood pressure } \\
\text { control }\end{array}$ & $\begin{array}{l}7 \text { days, } \\
\text { after } \\
\text { childbirth }\end{array}$ \\
\hline $\begin{array}{l}\text { Hoorn } \\
2016\end{array}$ & 16 & $\begin{array}{l}33.60 \\
\pm 5.30\end{array}$ & $\begin{array}{l}29.57 \\
\pm 2.30\end{array}$ & $\begin{array}{c}80 \mathrm{mg} / \mathrm{d} \text { aspirin } \\
+5000 \mathrm{U}^{*} \text { times } / \mathrm{d} \\
\text { LMWH }\end{array}$ & 16 & $\begin{array}{l}30.30 \\
\pm 4.20\end{array}$ & $\begin{array}{l}28.57 \\
\pm 3.10\end{array}$ & $\begin{array}{c}\text { Maternal and } \\
\text { fetal monitoring, } \\
\text { blood pressure } \\
\text { control }\end{array}$ & $\begin{array}{l}\text { During } \\
\text { treatment, } \\
\text { after } \\
\text { childbirth }\end{array}$ \\
\hline $\begin{array}{l}\mathrm{Li} \\
2019\end{array}$ & 28 & $\begin{array}{c}28.4 \\
\pm 3.40\end{array}$ & $\begin{array}{c}30.1 \\
\pm 3.80\end{array}$ & $\begin{array}{c}50 \mathrm{mg} / \mathrm{d} \text { aspirin } \\
+4000 \mathrm{U}^{*} \text { times } / \mathrm{d} \\
\text { LMWH }\end{array}$ & 28 & $\begin{array}{l}28.90 \\
\pm 3.70\end{array}$ & $\begin{array}{l}30.80 \\
\pm 4.10\end{array}$ & $\begin{array}{c}\text { Maternal and } \\
\text { fetal monitoring, } \\
\text { blood pressure } \\
\text { control }\end{array}$ & $\begin{array}{l}7 \text { days. } \\
\text { after } \\
\text { childbirth }\end{array}$ \\
\hline $\begin{array}{l}\text { Lu } \\
2018\end{array}$ & 41 & $\begin{array}{l}27.90 \\
\pm 3.90\end{array}$ & $\begin{array}{l}13.60 \\
\pm 2.30\end{array}$ & $\begin{array}{c}20 \mathrm{mg}^{*} 3 \text { times } / \mathrm{d} \\
\text { aspirin }+4000 \mathrm{U} / \mathrm{d} \\
\mathrm{LMWH}\end{array}$ & 41 & $\begin{array}{l}27.10 \\
\pm 4.30\end{array}$ & $\begin{array}{l}12.40 \\
\pm 2.70\end{array}$ & $\begin{array}{c}\text { Maternal and } \\
\text { fetal monitoring, } \\
\text { blood pressure } \\
\text { control }+25 \mathrm{mg}^{*} \\
3 \text { times/d aspirin }\end{array}$ & $\begin{array}{l}10 \text { weeks, } \\
\text { after } \\
\text { childbirth }\end{array}$ \\
\hline $\begin{array}{l}\text { Feng } \\
2019\end{array}$ & 52 & $\begin{array}{c}34.00 \\
\pm 11.00\end{array}$ & $\begin{array}{l}30.80 \\
\pm 2.20\end{array}$ & $\begin{array}{c}75 \mathrm{mg}^{*} \text { times/d } \\
\text { aspirin }+75 \mathrm{IU} / \\
\mathrm{kg}^{*} \text { times/d LMWH }\end{array}$ & 48 & $\begin{array}{l}31.40 \\
\pm 8.30\end{array}$ & $\begin{array}{l}29.80 \\
\pm 2.90\end{array}$ & $\begin{array}{l}\text { Maternal and } \\
\text { fetal monitoring, } \\
\text { blood pressure } \\
\text { control }+25 \% \\
\text { magnesium } \\
\text { sulfate }\end{array}$ & $\begin{array}{l}\text { During } \\
\text { treatment, } \\
\text { after } \\
\text { childbirth }\end{array}$ \\
\hline $\begin{array}{l}\text { Hong } \\
2019\end{array}$ & 40 & $\begin{array}{l}29.84 \\
\pm 2.27\end{array}$ & $\begin{array}{l}29.64 \\
\pm 1.24\end{array}$ & $\begin{array}{c}25 \mathrm{mg}^{*} \text { times/d } \\
\text { aspirin }+4000 \\
\text { U*times/d LMWH }^{\star} \text { L }\end{array}$ & 40 & $\begin{array}{l}29.16 \\
\pm 2.45\end{array}$ & $\begin{array}{l}29.13 \\
\pm 1.12\end{array}$ & $\begin{array}{c}\text { Maternal and } \\
\text { fetal monitoring, } \\
\text { blood pressure } \\
\text { control }\end{array}$ & 7 days \\
\hline
\end{tabular}

NA - not available, LMWH - low-molecular-weight heparin.

\section{APTT}

Five RCTs $[16,18-20,23]$ reported the APTT. There was statistical heterogeneity among the studies $\left(I^{2}=56 \%, p=0.06\right)$. Therefore, a random effect model was used. The synthesized outcome indicated that the difference in APTT between the two groups was statistically significant $(M D=$ 2.91, 95\% Cl: 2.06-3.75, $p<0.001$ ) (Figure $5 \mathrm{~A}$ ).

\section{FIB}

Four RCTs $[16,19,20,23]$ reported the FIB. There was no statistical heterogeneity among the studies $\left(I^{2}=38 \%, p=0.18\right)$. Therefore, fixed effect model was used. The synthesized outcome indicated that the difference in FIB between the two groups was statistically significant $(M D=-1.24$ 95\% Cl: $-1.32--1.15, p<0.001$ ) (Figure $5 \mathrm{~B}$ ).

\section{The adverse perinatal outcomes}

Four RCTs $[16,17,19,20]$ reported the adverse perinatal outcomes. There was statistical heterogeneity among the studies $\left(R^{2}=53 \%, p=0.009\right)$. Therefore, a random effect model was used. The synthesized outcome indicated that the difference in adverse perinatal outcomes between the two groups was statistically significant (MD $=0.41$, 95\% Cl: 0.20-0.85, $p=0.02$ ) (Figure $5 \mathrm{C}$ ).

\section{The adverse reactions of pregnant women}

Four RCTs $[16,17,19,21]$ reported the adverse reactions of pregnant women. There was no statistical heterogeneity among the studies $\left(R^{2}=0 \%\right.$, $p=0.65)$. Therefore, a random effect model was used. The synthesized outcome indicated that the difference in the adverse reactions of pregnant 
Random sequence generation (selection bias)

Allocation concealment (selection bias)

Blinding of participants and personnel (performance bias)

Blinding of outcome assessment (detection bias)

Incomplete outcome data (attrition bias)

Selective reporting (reporting bias)

Other bias
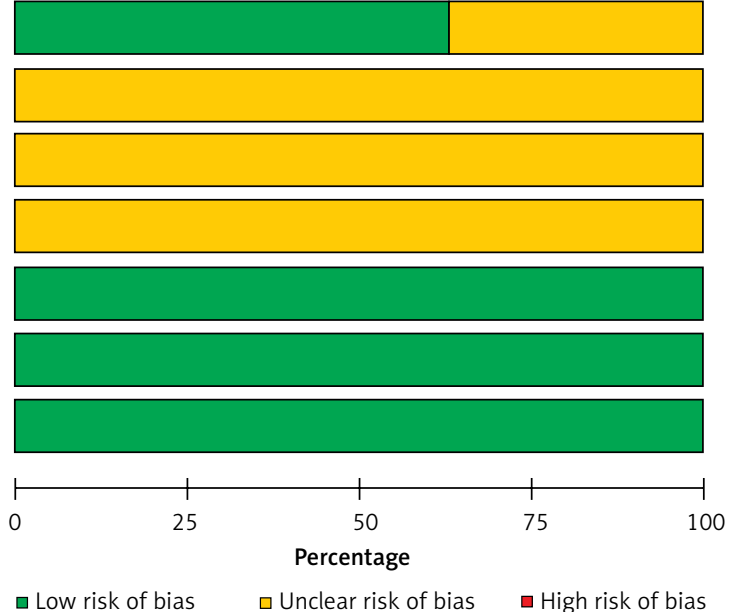

Figure 2. Risk of bias graph

women between the two groups was no statistically significant $(\mathrm{MD}=0.44,95 \% \mathrm{Cl}: 0.18-1.10$, $p=0.08$ ) (Figure $5 \mathrm{D}$ ).

\section{Publication bias}

The funnel plot on the synthesized outcomes is presented in Figure 6. Even though the funnel plot appeared to be asymmetrical, no publication biases were detected in all the synthesized outcomes (all $p>0.05$ ).

\section{Sensitivity analysis}

We excluded RCTs on each result one by one to see whether the overall results would change, and we found that the overall results were not changed by exclusion of any included RCTs.

\section{Discussion}

It is estimated that $4-5 \%$ of pregnant women in the world will suffer from eclampsia [24, 25]. PE brings a great burden in terms of the morbidity and mortality of mothers and babies, and has an important influence on the premature delivery of the fetus and the long-term cardiovascular disease of the mother [26]. The pathophysiological changes of PE include poor trophoblast infiltration, insufficient uterine spiral artery remodeling, and decreased uterine placental perfusion, resulting in clinical manifestations of placental donor insufficiency, leading to insufficient blood supply to the placenta $[27,28]$. In addition, this abnormal placenta formation leads to abnormal secretion of anti-angiogenesis and inflammatory proteins, which enter the maternal systemic circulation and damage the maternal systemic blood vessel function [29]. Therefore, early prevention, detection and treatment of PE are of great significance for the prognosis of patients.

Low-dose aspirin is considered the most effective preventive treatment, which can reduce the

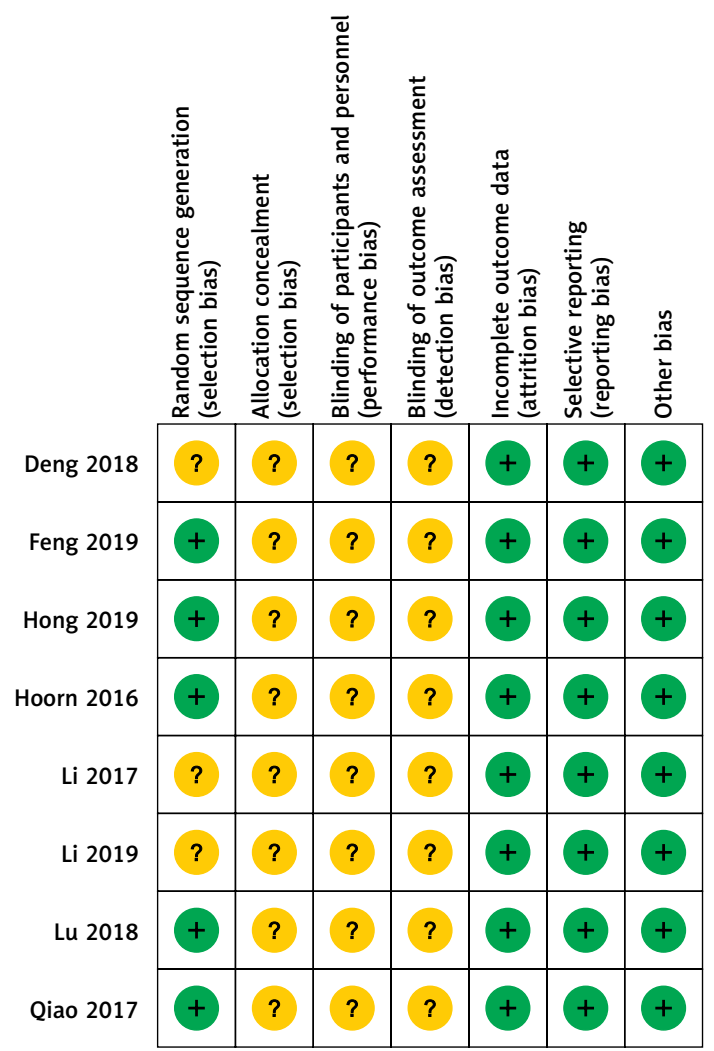

Figure 3. Risk of bias summary

prevalence of early-onset PE in women. It is generally believed that it is safe for pregnant women to use low-dose aspirin because it will not unintentionally affect the pregnant woman and (or) her unborn fetus [30]. Some researchers [31, 32] believe that the main mechanism of low-dose aspirin is to inhibit platelet aggregation by inhibiting the production of thromboxane. Also, low-dose aspirin has a direct positive effect on the villi trophoblast [33]. However, recent evidence [34] shows that low-dose aspirin prevents the development of preeclampsia by promoting the invasion and migration of trophoblast cells to the uterine ar- 
A Forest plot for systolic blood pressure

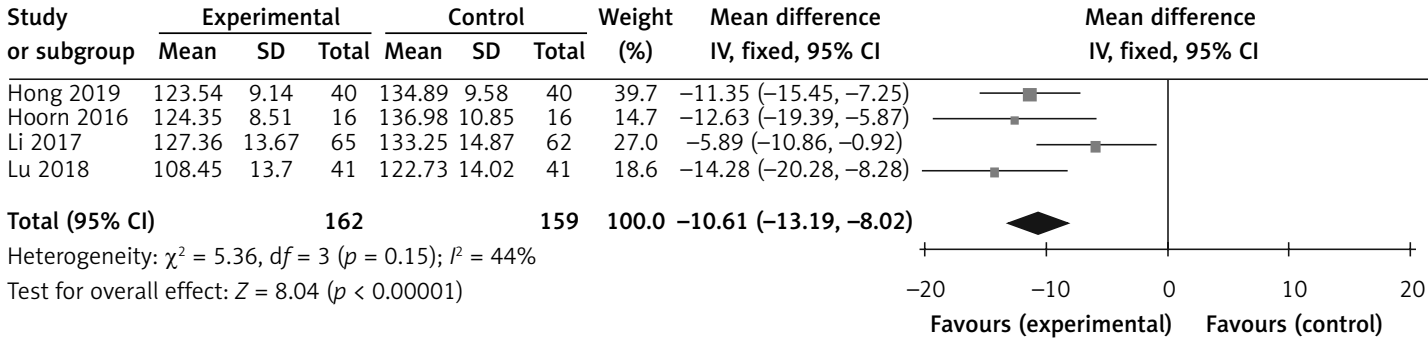

B Forest plot for diastolic blood pressure

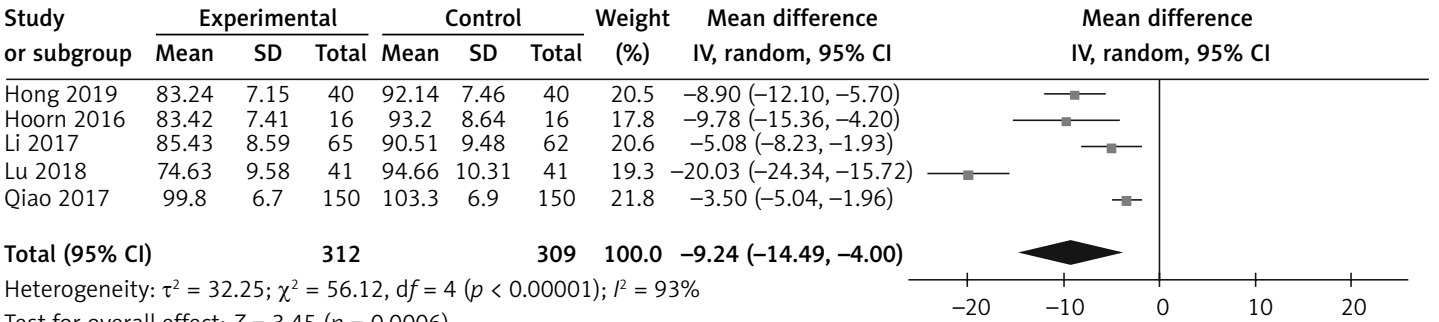

Test for overall effect: $Z=3.45(p=0.0006)$

Favours (experimental) Favours (control)

C Funnel plot for 24-hour urinary protein

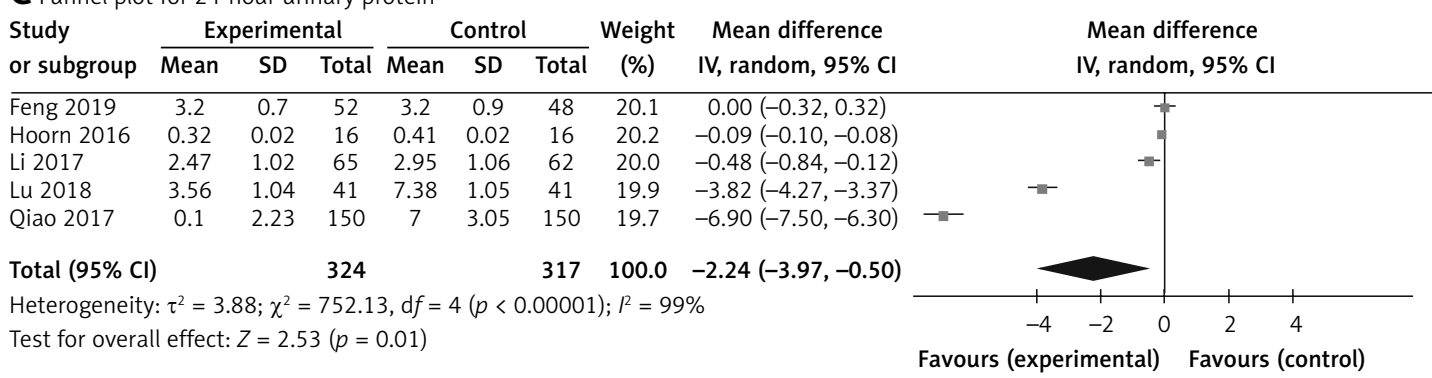

D Funnel plot for PT

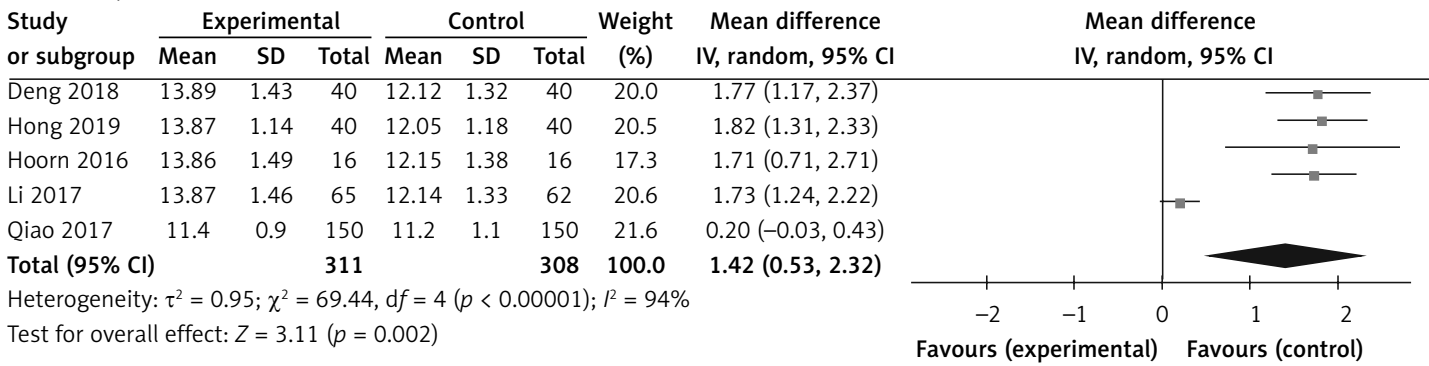

Figure 4. Forest plot for synthesized outcomes

tery, interfering with the production of cytokines, and stimulating the pro-angiogenic protein placental growth factor to prevent the development of preeclampsia, thereby inhibiting cell apoptosis and arterial remodeling. Studies [11, 35] have reported that low-dose aspirin taken by people at high risk of PE during gestational weeks 11-14 to 36 gestational weeks can significantly reduce the occurrence of preeclampsia. At the same time, when people with a high incidence of PE start taking aspirin and low molecular weight heparin before 16 weeks of pregnancy, it can effectively prevent PE [36]. The efficacy of aspirin and LMWH in the treatment of patients with preeclampsia remains to be verified. It has been reported that whether aspirin can improve the hypercoagulable state of pregnant women is related to its dose. If the dose is too small, the effect is not obvious. However, excessively large doses can lead to increased adverse reactions such as bleeding in patients [37].

We comprehensively evaluated the efficacy and safety of low-dose (< $150 \mathrm{mg} /$ day) aspirin combined with LMWH in the treatment of PE. The results showed that the blood pressure and 24-hour urine protein in the combined drug use group were significantly lower than in the control group, and 
A Forest plot for APTT

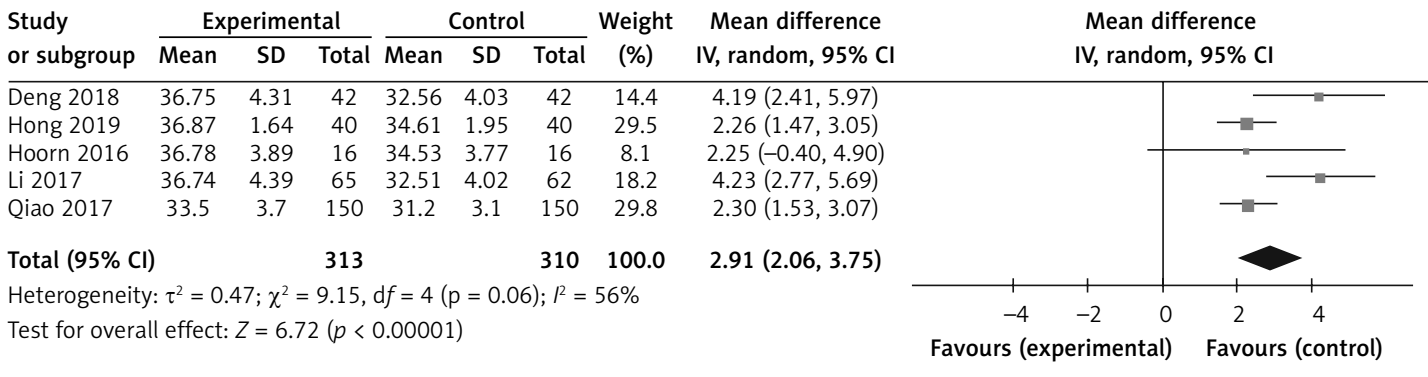

B Forest plot for FIB

\begin{tabular}{|c|c|c|c|c|c|c|c|c|c|c|c|}
\hline \multirow{2}{*}{$\begin{array}{l}\text { Study } \\
\text { or subgroup }\end{array}$} & \multicolumn{3}{|c|}{ Experimental } & \multicolumn{3}{|c|}{ Control } & \multirow{2}{*}{$\begin{array}{c}\text { Weight } \\
(\%)\end{array}$} & \multirow{2}{*}{$\begin{array}{l}\text { Mean difference } \\
\text { IV, fixed, } 95 \% \mathrm{Cl}\end{array}$} & \multirow{2}{*}{\multicolumn{2}{|c|}{$\begin{array}{l}\text { Mean difference } \\
\text { IV, fixed, } 95 \% \mathrm{Cl}\end{array}$}} & \\
\hline & Mean & SD & Total & Mean & SD & Total & & & & & \\
\hline Deng 2018 & 3.28 & 0.37 & 42 & 4.59 & 0.43 & 42 & 23.4 & $-1.31(-1.48,-1.14)-\square$ & & & \\
\hline Hong 2019 & 3.24 & 0.37 & 40 & 4.36 & 0.35 & 40 & 27.7 & $-1.12(-1.28,-0.96)$ & & & \\
\hline Hoorn 2016 & 3.23 & 0.36 & 16 & 4.34 & 0.4 & 16 & 9.9 & $-1.11(-1.37,-0.85)$ & & & \\
\hline Li 2017 & 3.27 & 0.35 & 65 & 4.58 & 0.41 & 62 & 39.0 & $-1.31(-1.44,-1.18)$ & & & \\
\hline \multicolumn{3}{|l|}{ Total $(95 \% \mathrm{Cl})$} & 163 & & & 160 & 100.0 & $-1.24(-1.32,-1.15)$ & & & \\
\hline \multicolumn{7}{|c|}{ Heterogeneity: $\chi^{2}=4.86, \mathrm{~d} f=3(p=0.18) ; l^{2}=38 \%$} & & & & & \\
\hline \multirow{2}{*}{\multicolumn{7}{|c|}{ Test for overall effect: $Z=29.22(p<0.00001)$}} & & -1.0 & -0.5 & 0.5 & 1.0 \\
\hline & & & & & & & & & \multicolumn{3}{|c|}{ Favours (experimental) Favours (control) } \\
\hline
\end{tabular}

C Forest plot for the adverse perinatal outcomes

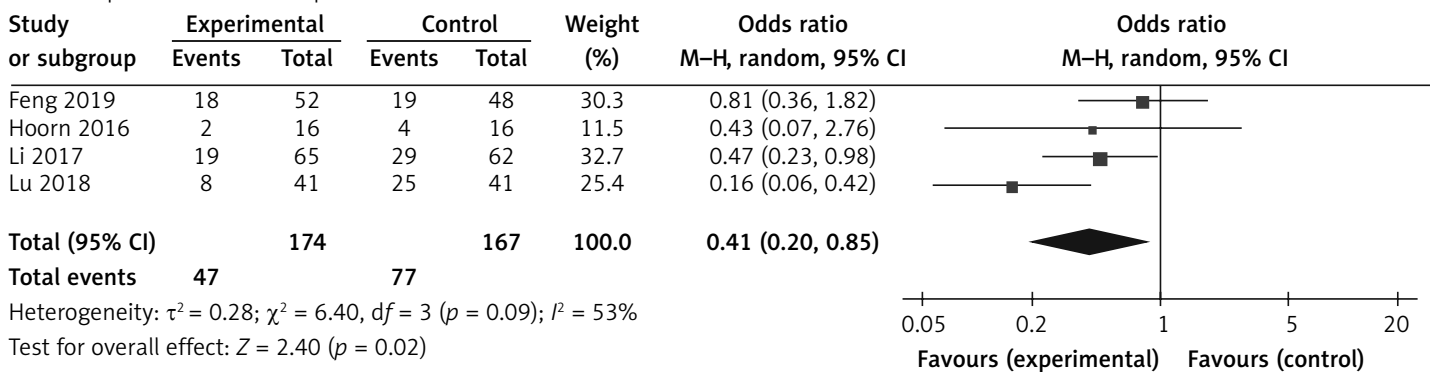

D Forest plot for the adverse reactions of pregnant women

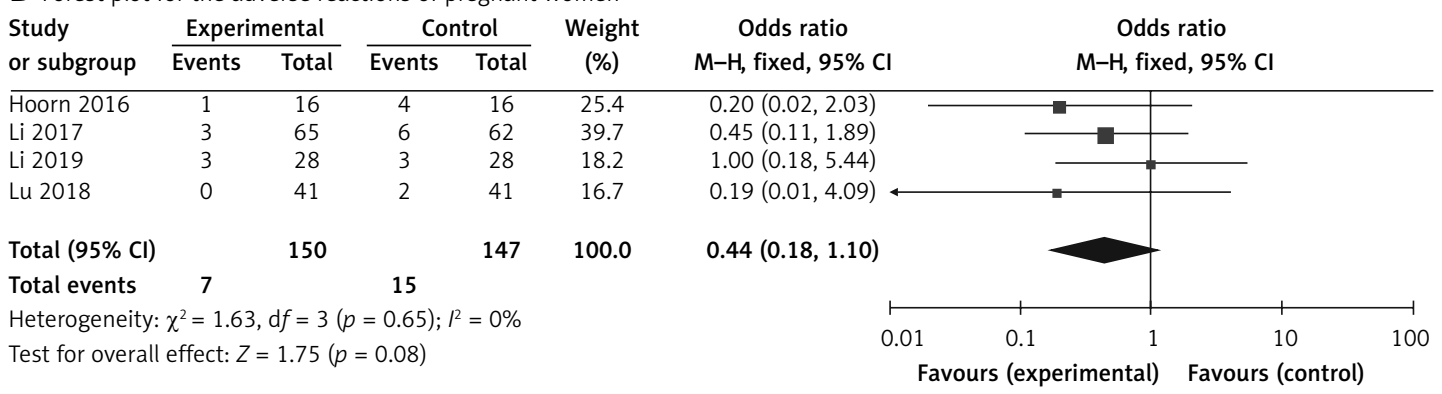

Figure 5. Forest plot for synthesized outcomes

its coagulation function (PT, APTT, FIB) was also significantly improved compared with the control group. This suggests that the combination of lowdose aspirin and LMWH has a significant effect in the treatment of PE. The possible reason is that LMWH is a commonly used clinical anticoagulant with anti-inflammatory, anti-immune and protective effects on the vascular endothelium [38]. Its small molecule characteristics make it easy to be absorbed by the body and have a long half-life, and it can also lead to the reduction of platelet aggregation and will ultimately reduce the patient's thrombosis [39]. Aspirin can inhibit the production of thromboxane, the final product of prostaglandin, by inhibiting cyclooxygenase, which hinders the formation of thrombus, and ultimately improves the clinical symptoms of patients with PE [40]. In addition, studies [41, 42] have shown that the combination therapy improves the soluble vascular endothelial growth factor receptor in patients and reduces the level of ultrasound parameters of placental blood perfusion, and increases the expression of angiogenesis genes in the placenta. This suggests that on the basis of conventional treatment, low-dose aspirin combined with LMWH can improve blood flow in the 
A Funnel plot for systolic blood pressure

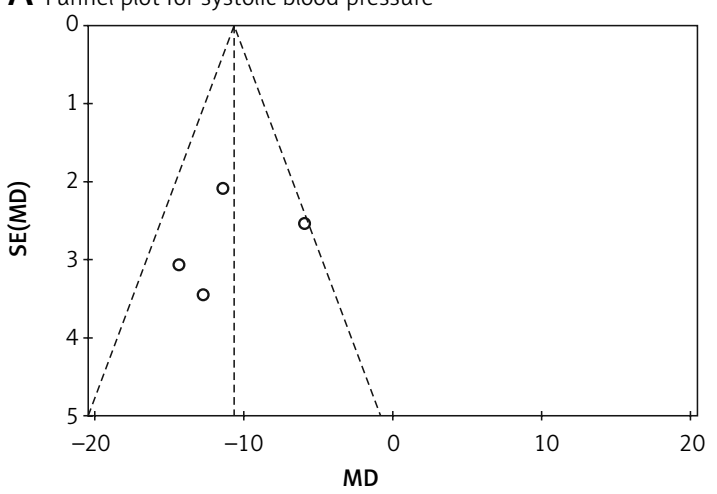

C Funnel plot for 24-hour urinary protein

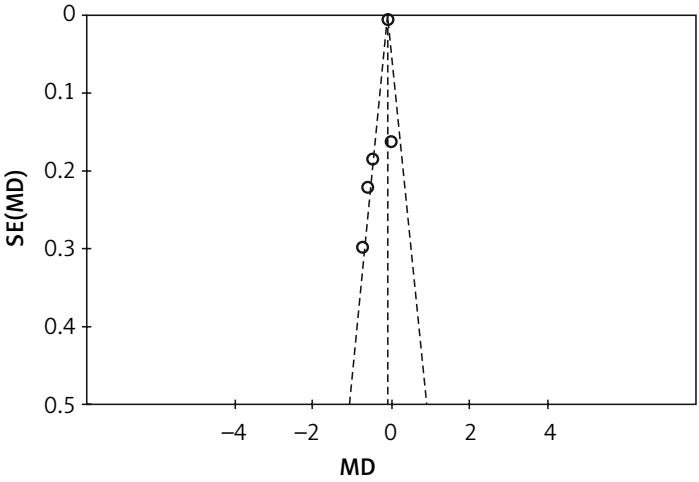

E Funnel plot for APTT

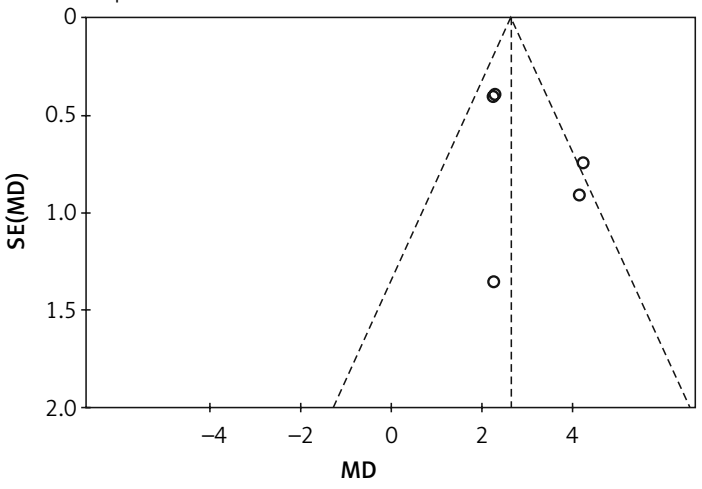

G Funnel plot for the adverse perinatal outcomes

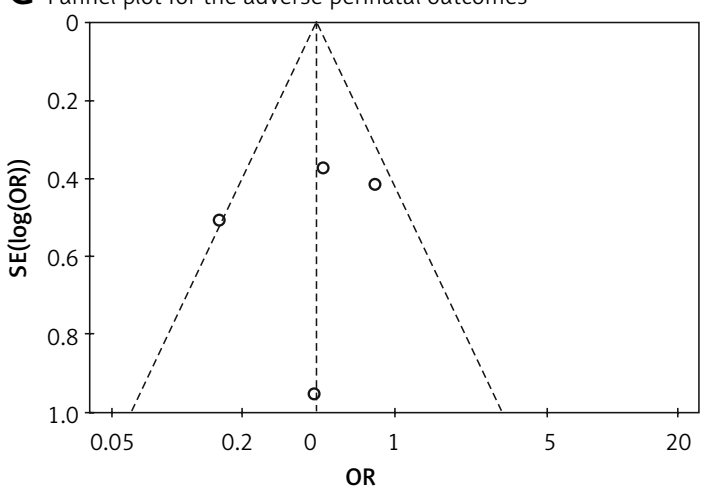

Figure 6. Funnel plot for synthesized outcomes
B Funnel plot for diastolic blood pressure

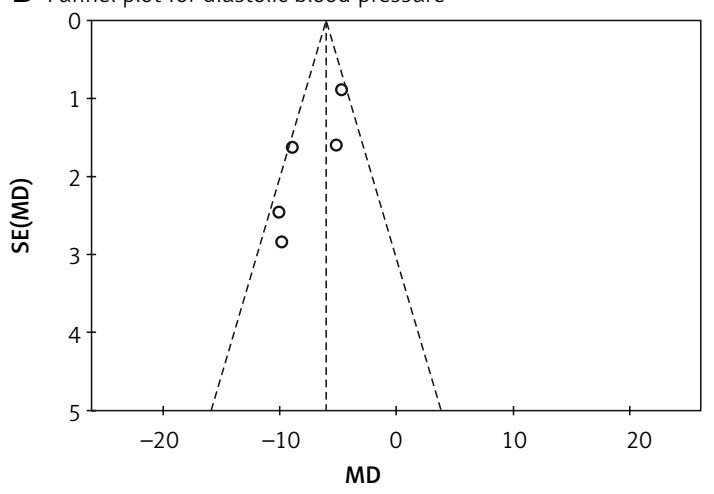

D Funnel plot for PT

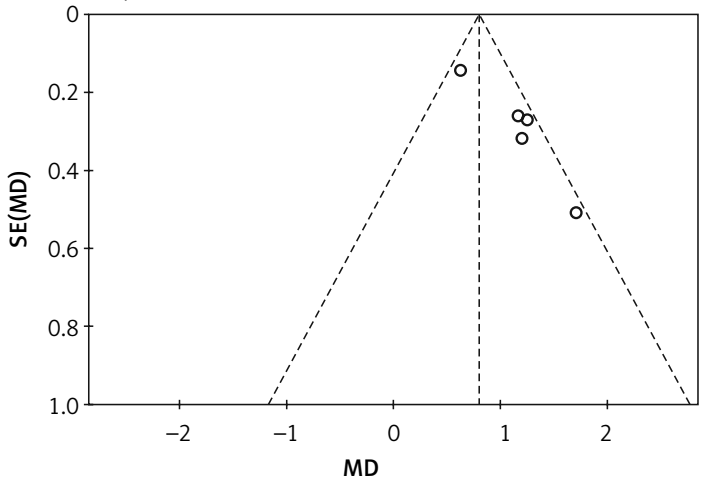

F Funnel plot for FIB

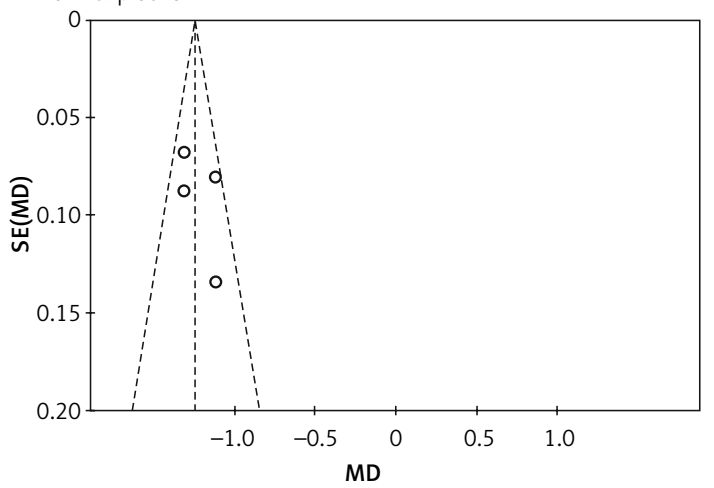

$\mathrm{H}$ Funnel plot for the adverse reactions of pregnant women

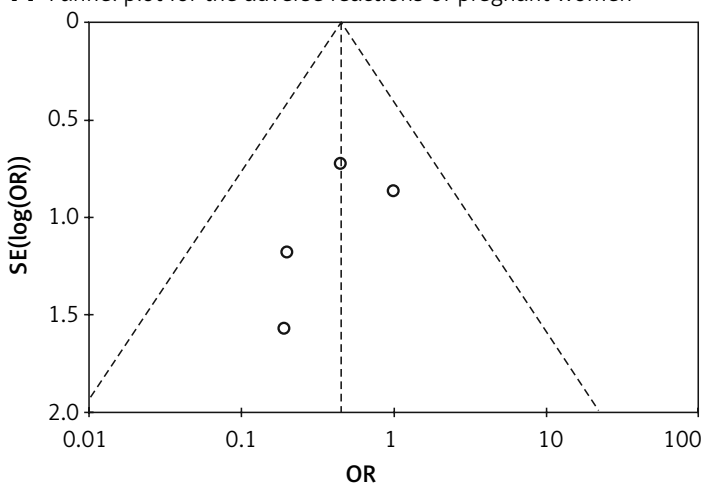


uterine spiral artery and increase placental blood perfusion. Currently, there are many reports [43, 44] on the active management of labor in women with hypertensive disorder or pre-eclampsia. Based on our findings, the combined use of lowdose aspirin and LMWH may be included in the active management of $P E$, which still needs further investigation in the future.

This study has the following limitations. Firstly, reports on the effects of aspirin combined with LMWH on PE in foreign countries are inconsistent. Most of the studies included in this meta-analysis are from China, and there is still a lack of high-quality research support from other regions. Secondly, the baseline characteristics of some of the included RCTs are incomplete, such as the lack of descriptions of gestational age and pregnancy details, and the outcome indicators of the included RCTs are not all consistent. Additionally, several studies [45-47] have reported the possible role of miRNAs in PE onset, both as increased or decreased expression in placenta or as maternal serum markers, which may be important outcomes for the evaluation of treatment effects and safety. Future studies focused more on the biological changes are needed. Thirdly, most outcome indicators in this present study are heterogeneous, limited by sample size, so we cannot perform more subgroup analysis. Therefore, the results of this study need to be further verified by a rigorously designed, large-sample, multi-center randomized controlled trial.

In conclusion, the use of low-dose aspirin combined with $\mathrm{LMWH}$ in the treatment of PE may be beneficial to improve blood pressure, 24hour proteinuria, and blood coagulation, and it may reduce the occurrence of adverse reactions of pregnant women without increasing adverse perinatal outcomes. Therefore, the effects and safety of low-dose aspirin combined with LMWH may provide a reference for the clinical treatment of PE. However, it is worth noting that the sample size of this meta-analysis is small, and the conclusions of this study need to be further elucidated in more high-quality studies with further in-depth analysis.

\section{Conflict of interest}

The authors declare no conflict of interest.

\section{References}

1. Rana S, Lemoine E, Granger JP, Karumanchi SA. Preeclampsia: pathophysiology, challenges, and perspectives. Circ Res 2019; 124: 1094-112.

2. Filipek A, Jurewicz E. Preeclampsia - a disease of pregnant women. Postepy Biochem 2018; 64: 232-29.

3. Auger N, Low N, Paradis G, Ayoub A, Fraser WD. Preeclampsia and the longitudinal risk of hospitalization for depression at 28 years. Soc Psychiatry Psychiatr Epidemiol 2021; 56: 429-36.

4. Cuckle H. Screening for early-onset preeclampsia. Am J Obstet Gynecol 2021; 224: 246.

5. DeCarlo C, Boitano LT, Molina RL, et al. Pregnancy and preeclampsia are associated with acute adverse peripheral arterial events. Arterioscler Thromb Vasc Biol 2021; 41: 526-33.

6. Boutin A, Guerby P, Gasse C, et al. Pregnancy outcomes in nulliparous women with positive first-trimester preterm preeclampsia screening test: the Great $\mathrm{Ob}$ stetrical Syndromes cohort study. Am J Obstet Gynecol 2021; 224: 204e201-204e207.

7. Reddy M, Fenn S, Rolnik DL, et al. The impact of the definition of preeclampsia on disease diagnosis and outcomes: a retrospective cohort study. Am J Obstet Gynecol 2021; 224: 217e211.

8. Hastie R, Tong S, Wikstrom AK, et al. Aspirin use during pregnancy and the risk of bleeding complications: a Swedish population-based cohort study. Am J Obstet Gynecol 2021; 224: 95e91-95e12.

9. Wright $\mathrm{D}$, Wright $\mathrm{A}$, Nicolaides $\mathrm{KH}$. The competing risk approach for prediction of preeclampsia. Am J Obstet Gynecol 2020; 223: 12-23e17.

10. Turbeville HR, Sasser JM. Preeclampsia beyond pregnancy: long-term consequences for mother and child. Am J Physiol Renal Physiol 2020; 318: F1315-26.

11. Roberge S, Demers S, Nicolaides $\mathrm{KH}$, et al. Prevention of pre-eclampsia by low-molecular-weight heparin in addition to aspirin: a meta-analysis. Ultrasound Obstet Gynecol 2016; 47: 548-53.

12. Karadag C, Akar B, Gonenc G, et al. Aspirin, low molecular weight heparin, or both in preventing pregnancy complications in women with recurrent pregnancy loss and factor $\mathrm{V}$ Leiden mutation. J Matern Fetal Neonatal Med 2020; 33: 1934-9.

13. Zhang Y, Shen F, Yang W, et al. Effects of low-molecular-weight heparin and aspirin in recurrent pre-eclampsia: a stratified cohort study. Int J Gynaecol Obstet 2020. doi: 10.1002/ijgo.13535.

14. Moher D, Liberati A, Tetzlaff J, et al. Preferred reporting items for systematic reviews and meta-analyses: the PRISMA statement. BMJ 2009; 339: b2535.

15. Higgins JP, Altman DG, Gotzsche PC, et al. The Cochrane Collaboration's tool for assessing risk of bias in randomised trials. BMJ 2011; 343: d5928.

16. van Hoorn ME, Hague WM, van Pampus MG, et al. Low-molecular-weight heparin and aspirin in the prevention of recurrent early-onset pre-eclampsia in women with antiphospholipid antibodies: the FRUIT-RCT. Eur J Obstet Gynecol Reprod Biol 2016; 197: 168-173.

17. Hongmei L, Hongyun C, Xiaohui L. Evaluation of the efficacy of aspirin combined with low molecular weight heparin in the treatment of pregnant women with severe preeclampsia. China Pharm 2018; 27: 67-9.

18. Zongxu Q. Efficacy analysis of low molecular weight heparin and aspirin in the treatment of preeclampsia. Chin J Clin Med 2007; 23: 652-3.

19. Yueping L, Qingfeng Y, Chunxia H. Evaluation of the efficacy of aspirin combined with low molecular weight heparin in the treatment of severe preeclampsia. Chongqing Med 2017; 46: 2965-7.

20. Yuelan D. The efficacy of aspirin combined with low molecular weight heparin in the treatment of severe preeclampsia. J Electrocardiogr 2018; 7: 226-7.

21. Zhihui L. The effect of low molecular weight heparin + aspirin on pregnancy outcome, endothelial injury and 
placental blood perfusion in pregnant women with preeclampsia. J Rational Drug Use China 2019; 16: 134-7.

22. Chunquan F. The clinical effect of antispasmodic, anticoagulant and the combination of the two in the treatment of mild preeclampsia. Guangxi Med 2019; 41: 510-3.

23. Lei H, Shuo G. The effect of low-molecular-weight heparin calcium combined with aspirin on blood pressure and coagulation function in patients with early-onset severe preeclampsia. Exploration Rational Drug Use China 2019; 16: 131-3.

24. Sun M, Fan Y, Hou Y, Fan Y. Preeclampsia and maternal risk of breast cancer: a meta-analysis of cohort studies. J Matern Fetal Neonatal Med 2018; 31: 2484-91.

25. Huang JL, Chen WK, Lin CL, Kao CH, Shih HM. Preeclampsia and the risk of pancreatitis: a nationwide, population-based cohort study. Gastroenterol Res Pract 2020; 2020: 3261542.

26. Xu TT, Zhou F, Deng CY, Huang GQ, Li JK, Wang XD. Lowdose aspirin for preventing preeclampsia and its complications: a meta-analysis. J Clin Hypertens 2015; 17: 567-73.

27. Ives CW, Sinkey R, Rajapreyar I, Tita ATN, Oparil S. Preeclampsia-pathophysiology and clinical presentations: state-of-the-art review. J Am Coll Cardiol 2020; 76: 1690-702.

28. Ahmed A, Rezai H, Broadway-Stringer S. Evidence-based revised view of the pathophysiology of preeclampsia. Adv Exp Med Biol 2017; 956: 355-74.

29. El-Sayed AAF. Preeclampsia: a review of the pathogenesis and possible management strategies based on its pathophysiological derangements. Taiwan J Obstet Gynecol 2017; 56: 593-8.

30. Dymara-Konopka W, Laskowska M, Oleszczuk J. Preeclampsia - current management and future approach. Curr Pharm Biotechnol 2018; 19: 786-96.

31. Wang X, Gao H. Prevention of preeclampsia in high-risk patients with low-molecular-weight heparin: a metaanalysis. J Matern Fetal Neonatal Med 2020; 33: 2202-8.

32. de Jong PG, Kaandorp S, Di Nisio M, Goddijn M, Middeldorp S. Aspirin and/or heparin for women with unexplained recurrent miscarriage with or without inherited thrombophilia. Cochrane Database Syst Rev 2014; 7 CD004734.

33. Groom KM, David AL. The role of aspirin, heparin, and other interventions in the prevention and treatment of fetal growth restriction. Am J Obstet Gynecol 2018; 218: S829-40.

34. Lefkou E, Varoudi K, Pombo J, et al. Triple therapy with pravastatin, low molecular weight heparin and low dose aspirin improves placental haemodynamics and pregnancy outcomes in obstetric antiphospholipid syndrome in mice and women through a nitric oxide-dependent mechanism. Biochem Pharmacol 2020; 182: 114217.

35. de Vries JI, van Pampus MG, Hague WM, Bezemer PD, Joosten JH, Investigators F. Low-molecular-weight heparin added to aspirin in the prevention of recurrent early-onset pre-eclampsia in women with inheritable thrombophilia: the FRUIT-RCT. J Thromb Haemost 2012; 10: 64-72.

36. Rodger MA, Gris JC, de Vries JIP, et al: Low-molecular-weight heparin and recurrent placenta-mediated pregnancy complications: a meta-analysis of individual patient data from randomised controlled trials. Lancet 2016; 388: 2629-41.
37. Sergio F, Maria Clara D, Gabriella F, et al. Prophylaxis of recurrent preeclampsia: low-molecular-weight heparin plus low-dose aspirin versus low-dose aspirin alone. Hypertens Pregnancy 2006; 25: 115-27.

38. Gebhart J, Posch F, Koder S, et al. High risk of adverse pregnancy outcomes in women with a persistent lupus anticoagulant. Blood Adv 2019; 3: 769-76.

39. Villa PM, Kajantie E, Raikkonen K, et al.; group PS. Aspirin in the prevention of pre-eclampsia in high-risk women: a randomised placebo-controlled PREDO Tria and a meta-analysis of randomised trials. BJOG 2013; 120: 64-74.

40. Lee EE, Jun JK, Lee EB. Management of women with antiphospholipid antibodies or antiphospholipid syndrome during pregnancy. J Korean Med Sci 2021; 36: e24.

41. Dutta S, Kumar S, Hyett J, Salomon C. Molecular targets of aspirin and prevention of preeclampsia and their potential association with circulating extracellular vesicles during pregnancy. Int J Mol Sci 2019; 20: 4370.

42. Tektonidou MG, Andreoli L, Limper M, Tincani A, Ward MM. Management of thrombotic and obstetric antiphospholipid syndrome: a systematic literature review informing the EULAR recommendations for the management of antiphospholipid syndrome in adults. RMD Open 2019; 5: e000924.

43. Gee SE, Ma'ayeh M, Cackovic H, et al. Addition of vaginal isosorbide mononitrate for labor induction in pregnancies complicated by hypertensive diseases of pregnancy: a randomized controlled trial. Am J Obstet Gynecol MFM 2021; 3: 100343.

44. Riemma G, La Verde M, Schiattarella A, et al. Efficacy of hyoscine butyl-bromide in shortening the active phase of labor: systematic review and meta-analysis of randomized trials. Eur J Obstet Gynecol Reprod Biol 2020; 252: 218-24.

45. Lagana AS, Vitale SG, Sapia F, et al. miRNA expression for early diagnosis of preeclampsia onset: hope or hype? Jatern Fetal Neonatal Med 2018; 31: 817-21.

46. Lei D, Fang C, Deng N, Yao B, Fan C. Long noncoding RNA expression profiling identifies MIR210HG as a novel molecule in severe preeclampsia. Life Sci 2021; 270: 119121.

47. Cheng D, Jiang S, Chen J, Li J, Ao L, Zhang Y. Upregulated long noncoding RNA Linc00261 in pre-eclampsia and its effect on trophoblast invasion and migration via regu lating miR-558/TIMP4 signaling pathway. J Cell Biochem 2019; 120: 13243-53. 